\title{
Beata : \\ Szczepańska Uniwersytet Łódzki \\ Działania bibliotek na rzecz kultury czytelniczej dzieci i młodzieży \\ Wybrane przykłady w Szwajcarii, we Włoszech i w Finlandii
}

$\mathrm{K}$

reowanie inspirującego czytanie dzieci i młodzieży środowiska odnaleźć można w działalności bibliotek różnych krajów. Wybrane przykłady pracy bibliotek w Szwajcarii, we Włoszech i w Finlandii zostały przedstawione uczestnikom projektu ADORE (Teaching Adolescent Struggling Readers. A Comparative Study of Good Practice in European Countries) realizowanego $\mathrm{w}$ ramach programu SOCRATES. Zaprezentowane przez autorkę materiały i obserwacje zostały zgromadzone w większości w czasie badań prowadzonych w związku z udziałem w tym projekcie w latach 2006-2009. W projekcie ADORE koncentrowano się na poszukiwaniu przykładów „dobrej praktyki” w pracy szkół - zwłaszcza poziomu średniego - w zakresie nabywania kompetencji czytelniczych przez uczniów w wieku adolescencji, mających problemy z czytaniem (Adolescent Struggling Readers). W uzupełnieniu głównego nurtu badań zapoznano uczestników z działalnością działów dla dzieci i młodzieży bibliotek w Winterthur (Szwajcaria), Ortonie (Włochy) i Jyväskylä (Finlandia).

Pierwsze z wymienionych miast - Winterthur położone jest w północno-zachodniej części Szwajcarii, w regionie Zurych. Biblioteka Miejska w Winterthur (WB) mieści się przy Obere Kirchgasse 6, a jej oddział naukowy (Studienbibliothek) - na Museumstrasse 52. W Winterthur i okolicy działa sześć filii tej biblioteki: Oberwinterhur, Hegi, Seen, Töss, Veltheim, Wülffingen. 


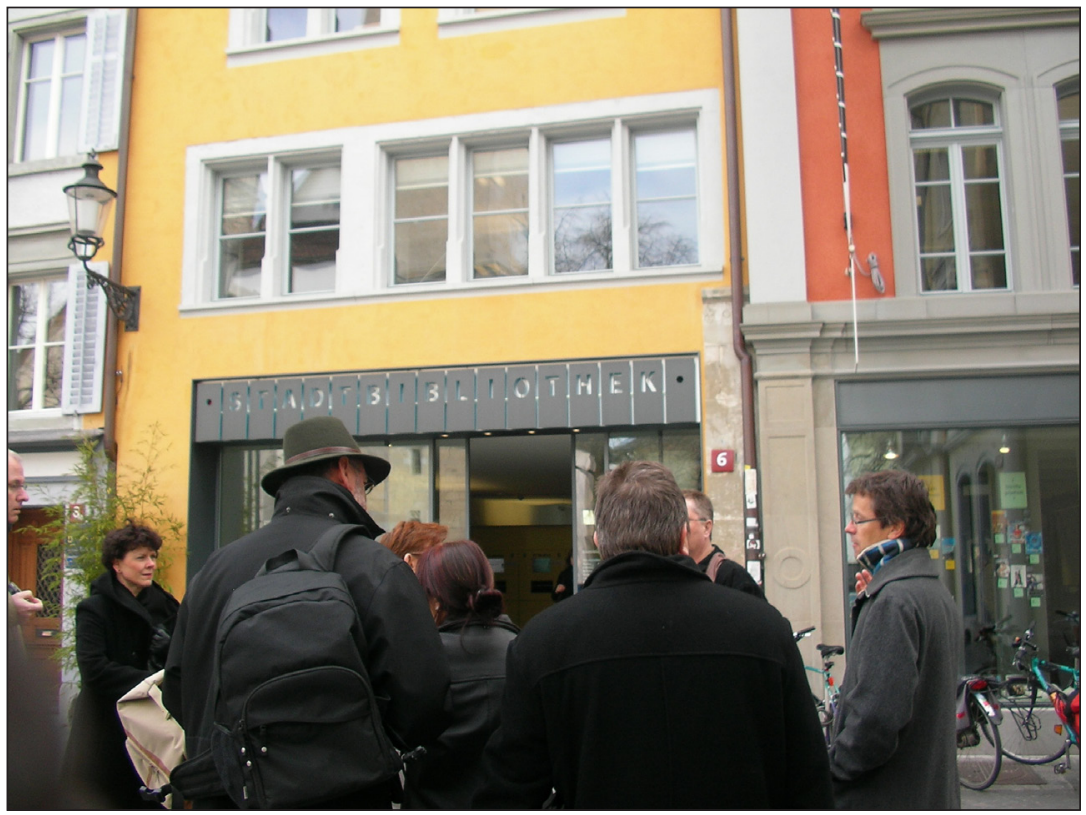

II. I.Wejście do Biblioteki Miejskiej wWinterthur

Źródło: fot. autorki, 6.03.2008 r.

W WB dział dziecięcy i młodzieżowy - Integrationsbibliothek für Kinder und Jugendliche („ib”- Kibiz) - stanowi wydzieloną część Biblioteki Języków Obcych / Biblioteki Integracyjnej - Integrationsbibliothek („ib”), a jego działalność uzupełnia specjalna sekcja dla młodzieży starszej, czy też, używając innego określenia, młodych dorosłych $U$ 21. Inne działy „ib” to sekcja literatury dla dorosłych i nauki języka niemieckiego. W pozostałych filiach WB też istnieją działy dziecięce i młodzieżowe, przy czym dolna granica wieku dzieci, które zapraszane są do mini-klubów - zawsze w towarzystwie dorosłych opiekunów - to drugi rok życia.

O specyfice działów dla dzieci i młodzieży WB stanowi dostosowany do wieku czytelników zarówno profil księgozbioru, jak i program działania. Sekcje te stanowią miejsce spotkań poszczególnych grup czytelników, stąd też są odpowiednio zorganizowane, zaprojektowa- 


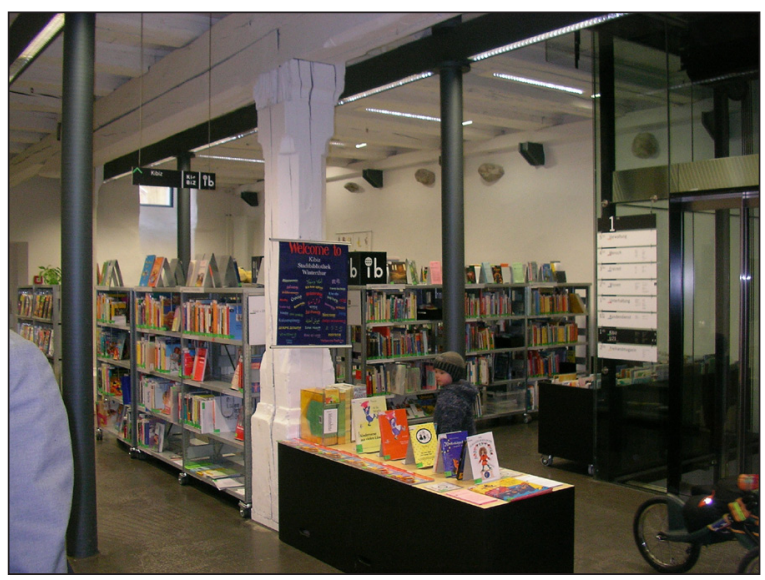

II. 2. Dział Dziecięcy Biblioteki Miejskiej w Winterthur, źródło: fot. autorki, 6.03.2008 r.

ne, urządzone i umeblowane stosownie do potrzeb, upodobań i gustów najmłodszych, młodszych i nieco starszych - górną granicę wiekową określa się na 21 rok życia - czytelników. Już sama nazwa całego dużego działu zapisywana małymi literami jako „ib” przypomina internetowe logo. W nazwie zawarty jest też głębszy sens - integracja językowa, a za pośrednictwem oferowanych mediów w różnych językach - także wielokulturowa.

II. 3. Dział Dziecięcy Biblioteki Miejskiej wWinterthur Źródło: fot. autorki, 6.03.2008 r.

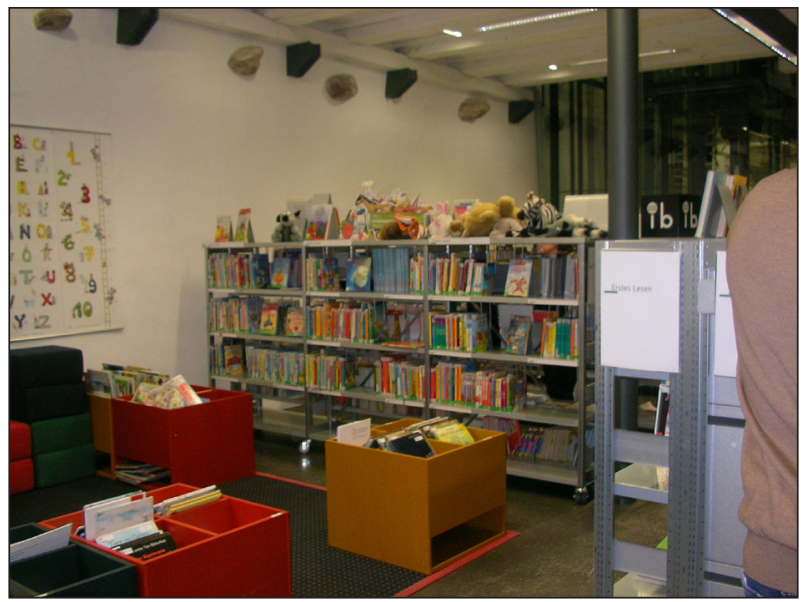




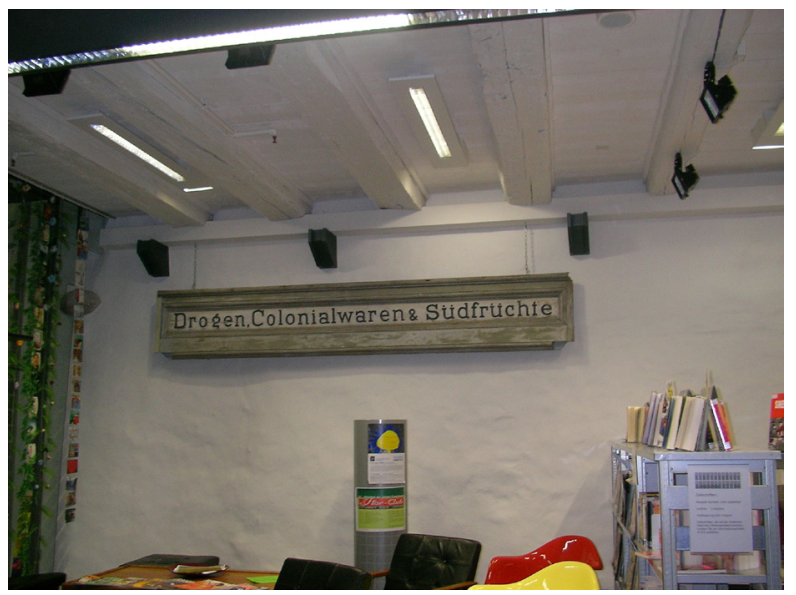

II. 4. U 2 I

w Bibliotece Miejskiej

wWinterthur

Źródło: fot. autorki, 6.03.2008 r.

Interesująco przebiegał projekt, który doprowadził do utworzenia działu U 21. Grupę, do której projekt ten był skierowany, tworzyli tzw. „trudni czytelnicy” - osoby pochodzące z rodzin społecznie marginalizowanych, niekorzystające z bibliotek, najczęściej rekrutujące się spośród imigranckich, a więc takie których językiem ojczystym nie był żaden z języków urzędowych Szwajcarii. Właśnie ta grupa „słabo umotywowanych" czytelników w wieku adolescencji zaczęła kreowanie

II. $5 . \cup 21$

w Bibliotece Miejskiej wWinterthur

Źródło: fot. autorki, 6.03.2008 r.

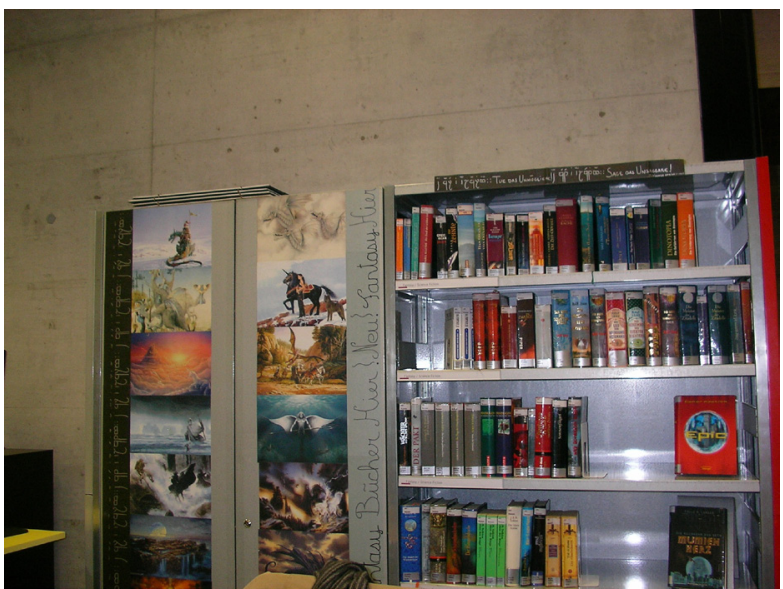


własnego pomysłu na bibliotekę w 2002 r. Przy wsparciu naukowców i bibliotekarzy określili oni, jaki „chcieliby by był” i jaki „być musi” dział U 21, zaplanowali strukturę księgozbioru samego działu, a nawet całej biblioteki. Celem grupy było również zaprojektowanie kształtu przestrzeni bibliotecznej poprzez dobór nie tylko mebli, ale też przez określenie kolorów wnętrza i jego wyposażenia, wybór rysunków, prac artystycznych, plakatów, a także określenie sposobu prezentacji poszczególnych mediów. Wybór zawartości udostępnianych zbiorów (książek, czasopism, CD, DVD, gier) dokonywany był przez wizyty w księgarniach, sesje online i dyskusje nad kryteriami selekcji. Obecnie sekcja U 21 stanowi przestrzeń, w której łączy się aktywność czytelniczą z - dokonywanym z własnego wyboru - rozwijającym spędzaniem wolnego czasu. Jest to punkt spotkań młodych ludzi z bibliotekarzami, miejsce pracy młodych ludzi, przestrzeń rekreacyjno-kawiarniana w środowisku zdominowanym przez różnego rodzaju media. Spotkania te łączą się z dyskusjami o książkach, artykułach, ale także o innowacjach w bibliotece, jej wystroju, wystawach. W trakcie spotkań projektowane są ulotki, strony internetowe. Przygotowuje się również "noce mediów”, seanse filmowe lub wizyty na imprezach kulturalnych. Młodzi ludzi zyskali przekonanie, że ich opinie, zainteresowania i wybory są traktowane poważnie. Dzięki odgrywaniu aktywnej roli w kompletowaniu zbiorów, nastąpiła identyfikacja grupy projektującej U 21 z „ich biblioteką”, zainteresowanie jej promowaniem i wprowadzaniem nowych czytelników. Poprzez dyskusję z bibliotekarzami i innymi ekspertami młodzi ludzie rozwinęli wiedzę o książkach, literaturze i mediach oraz nauczyli się je oceniać pod różnymi względami (poziom, przeznaczenie, zawartość) i pisać recenzje (Kruse G., Sommer T., 2010).

W efekcie prac projektowych zawartość księgozbioru „ib” stanowią pozycje zwarte i ciągłe dla dzieci i młodzieży w językach głównie: albańskim, angielskim, francuskim, włoskim, chorwackim, portugalskim, serbskim, hiszpańskim i tureckim. Można tutaj odnaleźć prace wydane w innych językach, na przykład po polsku, choć wyraźna jest koncentracja nie tylko na językach urzędowych Szwajcarii, ale można dostrzec stosunkowo dużo pozycji w językach narodowych najliczniej 
reprezentowanych grup imigrantów. Łącznie księgozbiór WB tworzą prace w 27 językach, a jego część stanowią prace dwu- lub więcej języczne.

Bardzo istotne wydaje się takie kompletowanie księgozbioru, aby zapewniał on kontakt $\mathrm{z}$ językiem ojczystym kraju pochodzenia imigrantów. Aktualnie wydawana w tych krajach literatura dziecięca i młodzieżowa jest za pośrednictwem ambasad szwajcarskich w nich działających kupowana i sprowadzana do WB. Na formowanie księgozbioru wciąż wywierają wpływ również czytelnicy. Projektem, w którym młodzi czytelnicy w wieku szkolnym mogli głosować na książki, by wybrać tę najulubieńszą był na przykład program SELEKTISSIMA (Hotz L., Sommer T., 2007).

Z kolei dla najmłodszych czytelników, a więc dwulatków przybywających do biblioteki WB lub jej filii w towarzystwie dorosłego opiekuna, organizowane są specjalne mini-cluby najczęściej działające latem, oferujące atrakcyjne, stosowne do wieku - formy promowania czytelnictwa. Dla dzieci w wieku przedszkolnym i wczesnoszkolnym organizowane są specjalnie aranżowane wycieczki po bibliotece oraz „kamishibai” i „media-pudełka” (Medienboxen). Japońska nazwa „kamisihibai" (kami - papier, shibai - sztuka) oznacza teatr obrazkowy lub teatr ilustracji. Drewniana skrzynka skonstruowana na wzór parawanu z teatrzyków marionetkowych, umożliwia pokazywanie kolejnych ilustracji stosownie do treści prezentowanych utworów literackich lub też plansz z obrazkami i tekstem. Wiosną 2012 roku były to na przykład: Owca Charlotta $i$ jej przyjaciele Henrika Wilsona, Rok z łabędziem Thomasa Müllera czy Historia byczka Leo - oparta na prawdziwych zdarzeniach i relacjach prasowych (Library Oberwinterthur, 2012 [on-line]). Ciekawa forma artystyczna serii obrazków, tematyka dobrana pod kątem zainteresowań dzieci w tym wieku, a także możliwość regulowania tempa pojawiania się przesuwanych odpowiednio do lektury tekstu i zainteresowania odbiorców obrazków powodują, że „kamishibai” cieszy się dużym i niesłabnącym zainteresowaniem. Jest to bowiem swoistą formą przedstawień teatralnych dla dzieci.

Natomiast „media-pudełka” są stosowane najczęściej w pracy z grupami dzieci, które mają wspólnie opracować jakieś zagadnienie. 
Różnorodne media dotyczące tematu w ilości odpowiedniej dla jednej klasy umieszcza się w przygotowanym pudełku określonego koloru. Zawartość takiego „media-pudełka”, wcześniej wyselekcjonowana przez bibliotekarzy pomaga dzieciom współpracować przy realizacji tematu. Mogą być przygotowywane także na indywidualne zamówienia (Bibliotheken, 2006).

Dla dzieci, które zaczynają swoją inicjację biblioteczną, przygotowana została seria zeszytów do wypełnienia początkowo rysunkami, a dla bardziej zaawansowanych w nauce czytania i pisania - do uzupełnienia wpisami o przeczytanych książkach, wykorzystywanych w bibliotece mediach oraz o funkcjonowaniu biblioteki. W tworzeniu tej serii o bardzo atrakcyjnej formie plastycznej i edytorskiej brała udział przedstawicielka środowiska naukowego - z Wyższej Szkoły Pedagogicznej w Zurychu oraz doświadczona bibliotekarka WB. Seria „Biblioheft” wydana została przez władze miejskie Wintherthur (Amrein K., Furrer Y., 2008).

W księgozbiorze Biblioteki Integracyjnej WB znajdują się również pozycje dwu- i wielojęzyczne promujące język niemiecki i ułatwiające integrację dzieci, młodzieży i dorosłych z odmiennych grup etnicznych. Temu celowi służą również kursy różnych języków i kultur organizowane przez WB przy współpracy z Miejskim Instytutem Integracyjnym i Międzykulturowym Centrum w Winterthur. Centrum to jest również partnerem projektu Bibliotek Winterthur, wspieranego przez władze Konfederacji Szwajcarskiej i Kantonu Zurych.

Nauczyciele w „ib” mogą znaleźć materiały dotyczące tematu imigracji, historii wielokulturowej, integracji i pedagogiki międzykulturowej. Ta część księgozbioru ma służyć jako wsparcie dla nauczycieli pracujących z klasami szkolnymi o (co częste w Szwajcarii) międzynarodowym składzie.

WB współpracuje z Centrum Czytania (Zentrum Lesen), działającym w ramach Instytutu Badań i Rozwoju (Institut Forschung and Entwicklung) Wyższej Szkoły Pedagogicznej Północno-Zachodniej Szwajcarii (Pädagogische Hochschule - FHNW) w Aarau zarówno w zakresie promowania czytelnictwa wśród uczniów szwajcarskich szkół, jak i dokształcania oraz doskonalenia nauczycieli pod kątem 
rozwijania kompetencji czytelniczych dzieci i młodzieży, a za pośrednictwem tej uczelni także z: Uniwersytetem w Bazylei, Wyższą Szkołą Pedagogiczną w Bernie i Uniwersytetem we Fryburgu (Schneider H., 2007). Centrum Czytania w Aarau wydaje własne czasopismo bardzo przydatne w praktyce szkolnej - „Rundschreiben Zentrum Lesen”, które ogniskuje działania naukowców i bibliotekarzy-praktyków na rzecz promowania czytelnictwa w środowisku szkolnym i pozaszkolnym.

Przy okazji realizacji zadań projektu ADORE nawiązana została bliższa współpraca naukowców Regionalnego Instytutu Badań Edukacyjnych (IRRE) w L’Aquili z Biblioteką Komunalną (BK) w Ortonie. Miasto to należące do regionu Abruzja, położone jest w środkowo-wschodniej części Włoch. BK działa w ramach Systemu Bibliotek Prowincji Chieti. Początki jej działalności w Ortonie sięgają roku 1908, gdy grupa studentów założyła w tej pięknej nadmorskiej miejscowości Koło Kultury Popularnej (Ortona Biblioteca, 2012 [online]), choć wskazuje się także wcześniejsze - pochodzące z pierwszej połowy XIX wieku - inicjatywy w tym zakresie (Piccole... 2007).

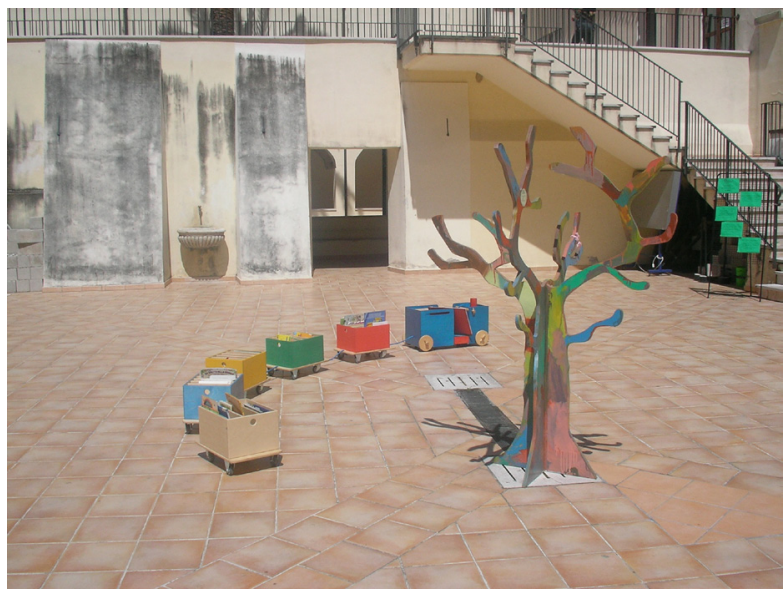

II. 6. Wejście do Biblioteki Miejskiej w Ortonie Źródło: fot. autorki, 22.04.2008 r.

BK w Ortonie jest zlokalizowana na Corso Garibaldi. Prowadzi wyspecjalizowaną aktywność na rzecz dzieci i młodzieży poprzez Cen- 
tro Sistema Ragazzi (CESIRA) oraz Centro Interattivo Prima Infanzia (CIPI). Przestrzeń placówki stanowią: czytelnia prasy, czytelnia naukowa, sala dla młodzieży, obszar dla dzieci najmłodszych, sekcja wystaw, sala spotkań klubowych.

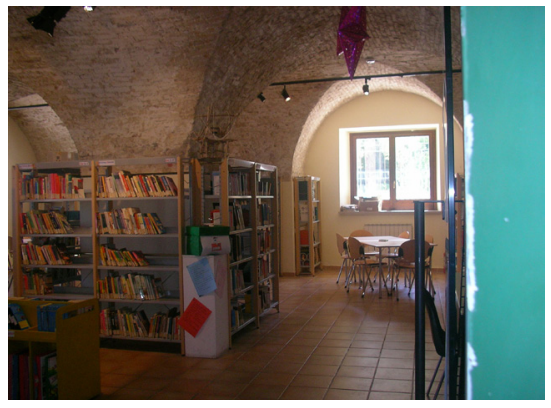

II. 7. Dział Dziecięcy w Bibliotece Miejskiej w Ortonie

Źródło: fot. autorki, 22.04.2008 r.

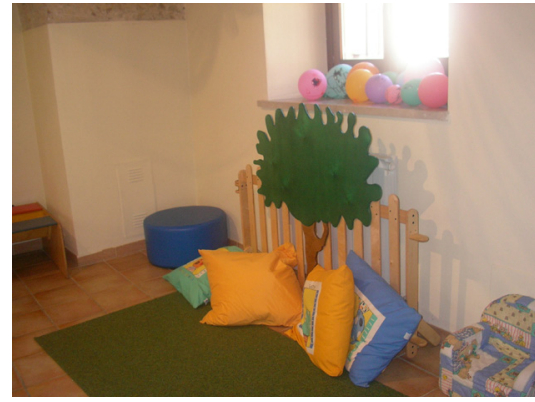

II. 8. Strefa dla dzieci najmłodszych w Bibliotece Miejskiej w Ortonie

Źródło: fot. autorki, 22.04 .2008 r.

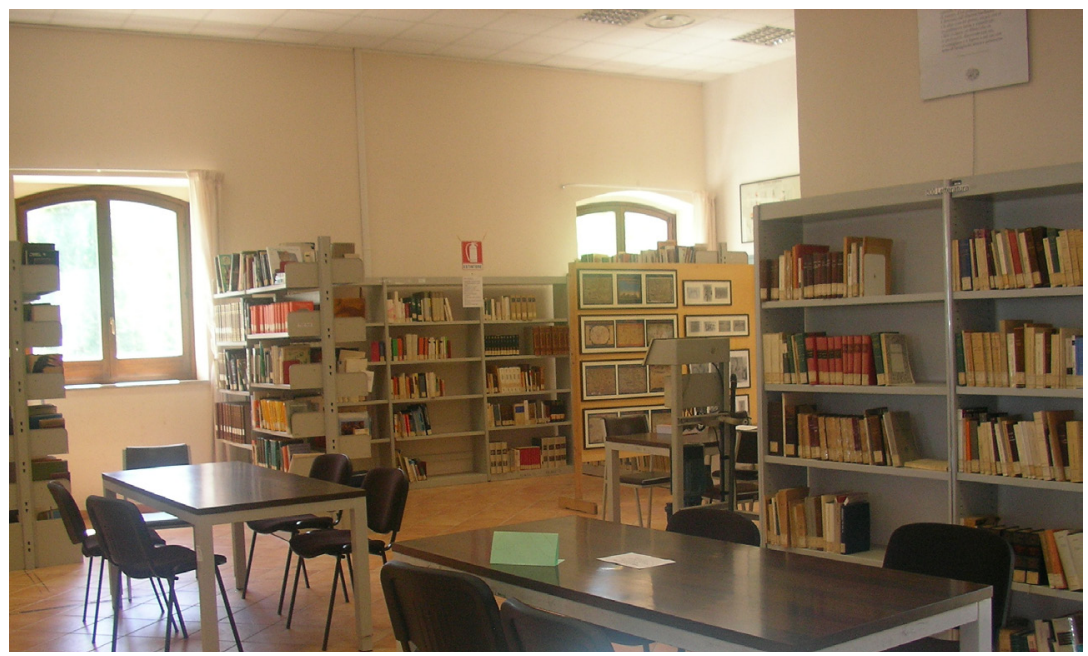

II. 9. Czytelnia Naukowa w Bibliotece Miejskiej w Ortonie Źródło: fot. autorki, 22.04.2008 r. 
W programie działania BK w Ortonie mocno akcentowane są działania na rzecz promowania czytelnictwa dzieci i młodzieży przy współpracy ze szkołami i rodzicami młodych czytelników lub kandydatów na nich. Projekt Przyjemność czytania realizowany w Średniej Szkole Muzycznej Chiarini - De Lollis stanowi przykład takiej współpracy.

Główne celu projektu to: rozwijanie satysfakcji z czytania, sprawianie, aby uczniowie dobrze się czuli w bibliotekach i chętnie z nich korzystali oraz doskonalenie umiejętności czytania i rozumienia tekstów. Wśród działań podejmowanych w ramach tego projektu wymienić można m.in.:

- reorganizowanie przestrzeni szkolnej biblioteki przy użyciu materiałów graficznych wykonanych przez uczniów i tworzenie typologii tekstów,

- animacje przedstawiające nowości w bibliotece,

- walizeczki „wędrujące” pomiędzy klasami, zawierające wybrane książki,

- wizyty uczniów w bibliotekach i „oswajanie się” z ich przestrzenią i regułami w nich obowiązującymi (Fiordigili I., Toscano E., 2008).

Z kolei Innowacyjne Centrum Interaktywne Pierwszego Dzieciństwa (CIPI) powstało w 1997 r. w ramach lokalnej akcji na rzecz podnoszenia jakości edukacji, dla której inspirację stanowił projekt międzynarodowy Born to Read. Był on wspierany przez Towarzystwo Pediatryczne i Stowarzyszenie Bibliotek Włoskich. Przy tworzeniu CIPI wzięto pod uwage sformułowane przez UNESCO zalecenia i parametry określone ze szczególną troską w stosunku do dzieci, które mogły zaczynać swą inicjację biblioteczną w wieku 18 miesięcy. Obecność członków rodziny była absolutnie konieczna, stąd też godziny otwarcia CIPI to dwa dni tygodnia w godz. 16-18 i soboty w godz. 10-12. Tak wczesny, właściwie zaaranżowany kontakt dziecka z literaturą, miał zdaniem organizatorów projektu stworzyć warunki do pełnego rozwoju osobowości dziecka. Przy okazji chciano przekazać wskazówki dotyczące dziecięcego kontaktu z książką - rodzicom lub opiekunom przebywającymi wraz z dziećmi w Centrum. 
CIPI jako uczestnik Globalnej Akcji na Rzecz Dzieci zakładał także cele ogólniejszej natury, np. ochronę praw dziecka, propagowanie szczęśliwego dzieciństwa, propagandę pacyfistyczną, walkę z AIDS.

Uzupełnienie i wzmocnienie promowania czytelnictwa wśród dzieci i młodzieży prowadzonego przez BK stanowi wydawanie od 2003 r. własnego czasopisma „Biblio-Ragazzi”, które stanowi dodatek do ukazującego się z inicjatywy Systemu Bibliotecznego Prowincji Chieti czasopisma „Libri in Rete”.

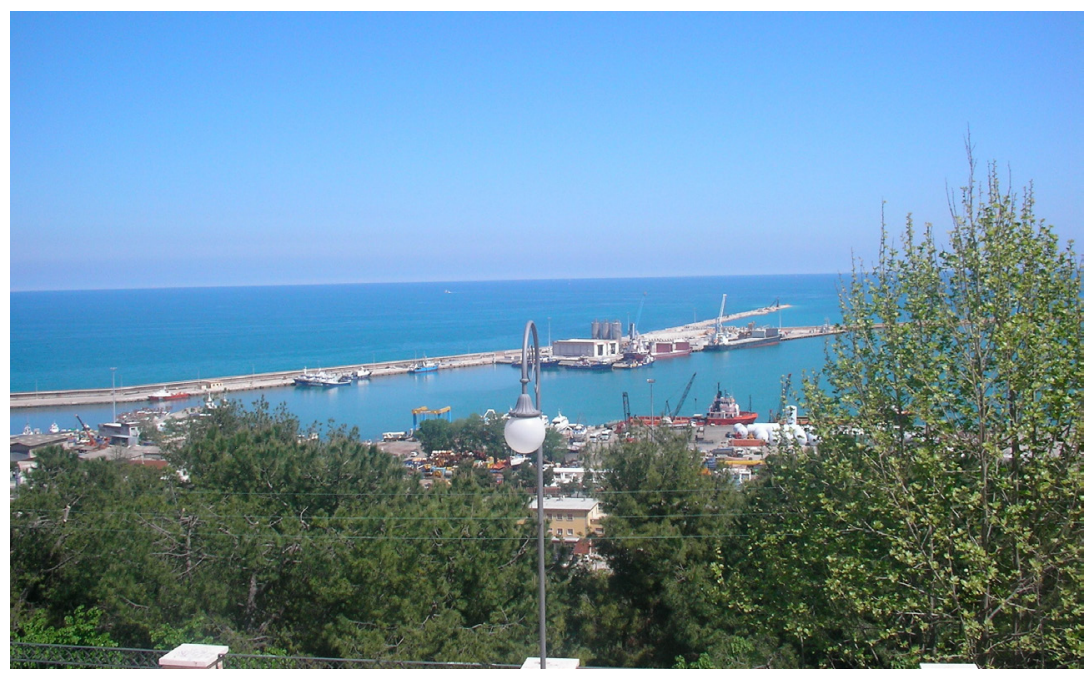

II. IO.Widok z okien Biblioteki Miejskiej w Ortonie Źródło: fot. autorki, 22.04.2008 r.

Warto także dodać, że ze względu na nadmorski charakter Ortony okres wakacyjny wykorzystywany jest również bardzo intensywnie do działań na rzecz upowszechniania kultury czytelniczej przyjezdnych i miejscowych dzieci i młodzieży, które odbywają się pod hasłem Książki i wakacje. Wśród podejmowanych w 2003 r. inicjatyw w tym zakresie wymienić można:

- przegląd literacki pn. „Książki i morze”,

- warsztaty i przedstawienia pt."Wyspa, której nie ma”, 
- „Przyjaciel-książka”-czytanie, przedstawianie, interpretowanie,

- konkurs literacki Nie zgodzę się z autorem... (Libri in vacanza, 2003).

Główna siedziba Regionalnej Biblioteki Środkowej Finlandii, bo taką nazwą Miejska Publiczna Biblioteka w Jyväskylä jest również określana, znajduje się na ul. Vapaudenkatu 39/41. Biblioteka ta posiada 7 filii położonych w Jyväskylä oraz jedną usytuowaną poza tym dość rozległym, położonym wśród jezior miastem - w Säynätsalo. Region Jyväskylä, który nazywany jest „sercem Finlandii”, zyskał sobie też miano „miejsca urodzenia fińskiej edukacji językowej”. Wiąże się to z faktem, iż właśnie w tej miejscowości założono w 1863 r. działające do dziś w ramach Uniwersytetu w Jyväskylä - Kolegium Nauczycieli Języka Fińskiego, którego pierwszym rektorem był Uno Cyganeus.

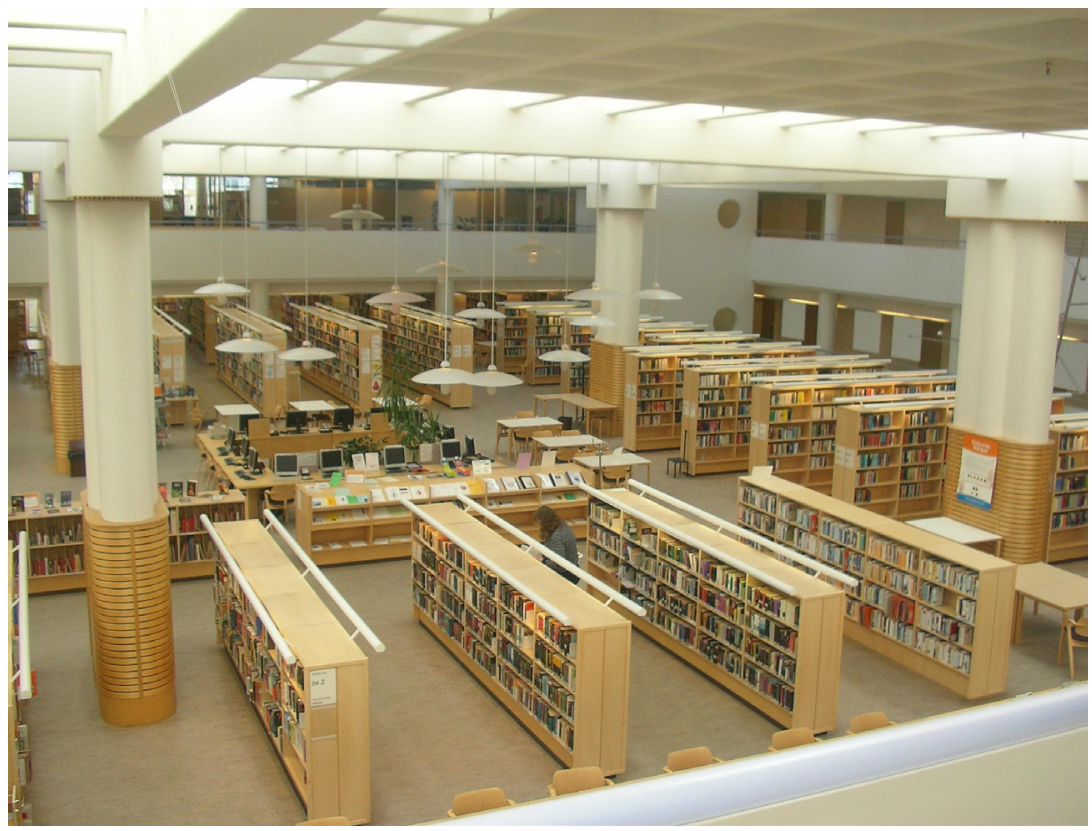

II. II.Wnętrze Biblioteki Miejskiej w Jyvaskyla

Źródło: fot. autorki, 5.05.2008 r. 


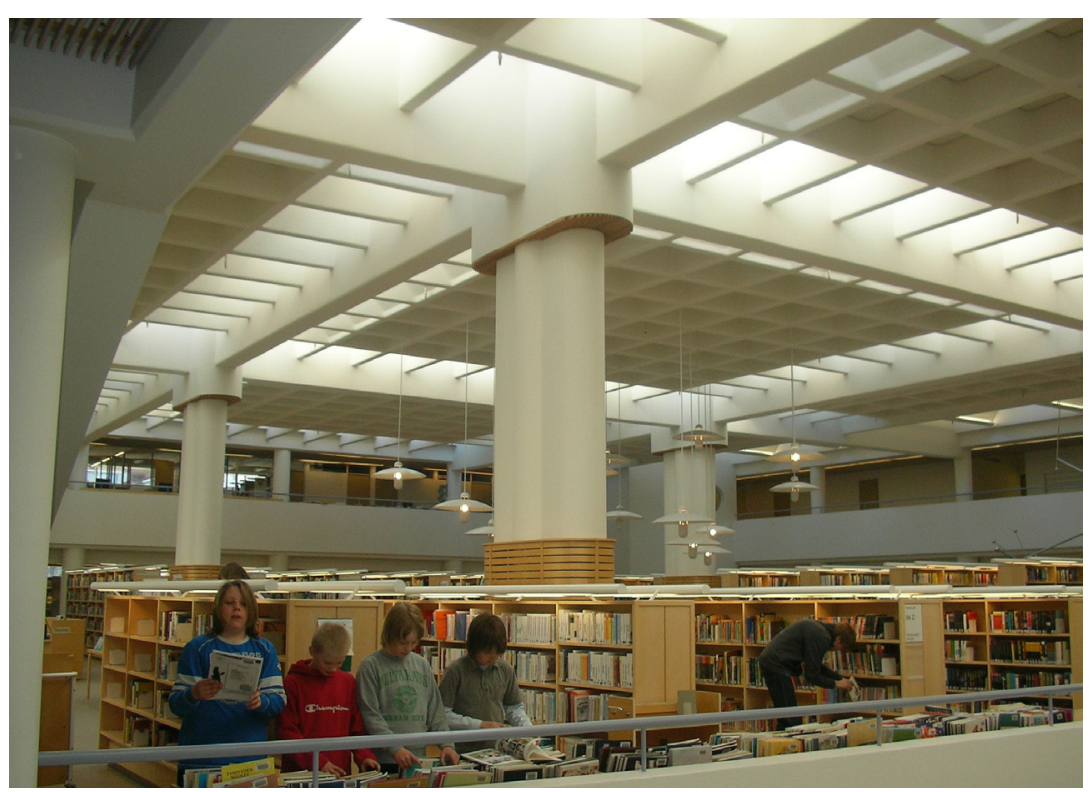

II. 12. Młodzi czytelnicy w Bibliotece Miejskiej w Jyvaskyla

Źródło: fot. autorki, 5.05.2008 r.

W Miejskiej Bibliotece Publicznej wydzielone są następujące działy: Dziecięcy i Młodzieżowy, Muzyczny oraz Ruchomej Biblioteki (ten dział z uwagi na swój mobilny charakter zlokalizowany jest w autobusie). Projekt architektoniczny siedziby CLoJ stworzył znany fiński designer Alvar Aalto (Welcome... 2004, s. 5, 7).

Wnętrze biblioteki pełne jest światła i przestrzeni, regały na książki, stoły, krzesła i inne detale dodatkowo potęgują takie wrażenie, gdyż wykonane są z jasnego, brzozowego drewna. Funkcjonalne urządzenie wnętrza biblioteki zapewnia swobodę poruszania się i umożliwia nieograniczony dostęp do zgromadzonych tutaj woluminów i innych mediów; daje też szanse na organizowanie imprez czasowych, a wydzielone „enklawy ciszy” pozwalają na koncentrację uwagi na lekturze.

Oferta CLoJ dla najmłodszych czytelników obejmuje literaturę dziecięcą, muzykę, komiksy, magazyny, filmy (video, CD, DVD). 
Z kolei dla młodzieży CLoJ poleca:

- informatory (nawet „od takich o bandach do takich o seksie i randkach"),

- atlasy, słowniki, kalendarze,

- literaturę przygodową i romantyczną,

- książki „do słuchania i oglądania”,

- muzykę,

- magazyny i komiksy.

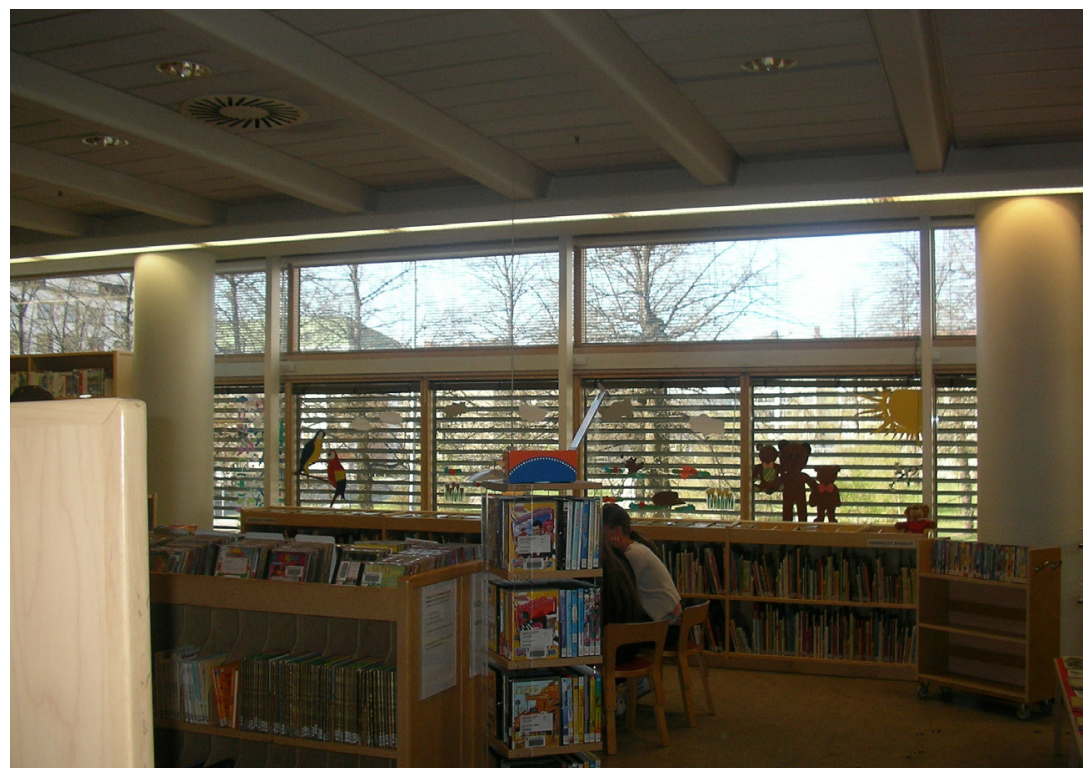

II. I 3. Dział Dziecięcy i Młodzieżowy Biblioteki w Jyvaskyla

Źródło: fot. autorki, 5.05.2008 r.

Grupie tych czytelników oferowane są interesujące ponadto pozycje, nie tylko mieszczące się w kategorii tradycyjnie pojmowanej literatury, ale mocno też przyciągające młodzież - multimedia.

Wśród propozycji dla dzieci i młodzieży, które poleca CLoJ jako „inne miłe rzeczy” znajdujemy także: 
- $\quad$ wystawy książek i dzieł sztuki,

- quizy i konkursy,

- teatr dziecięcy i inne imprezy,

- komputery do surfowania po Internecie oraz do odtwarzania muzyki,

- możliwość słuchania muzyki i opowiadań,

- cichą przestrzeń do czytania,

- „przyjaciół na i pomiędzy półkami”.

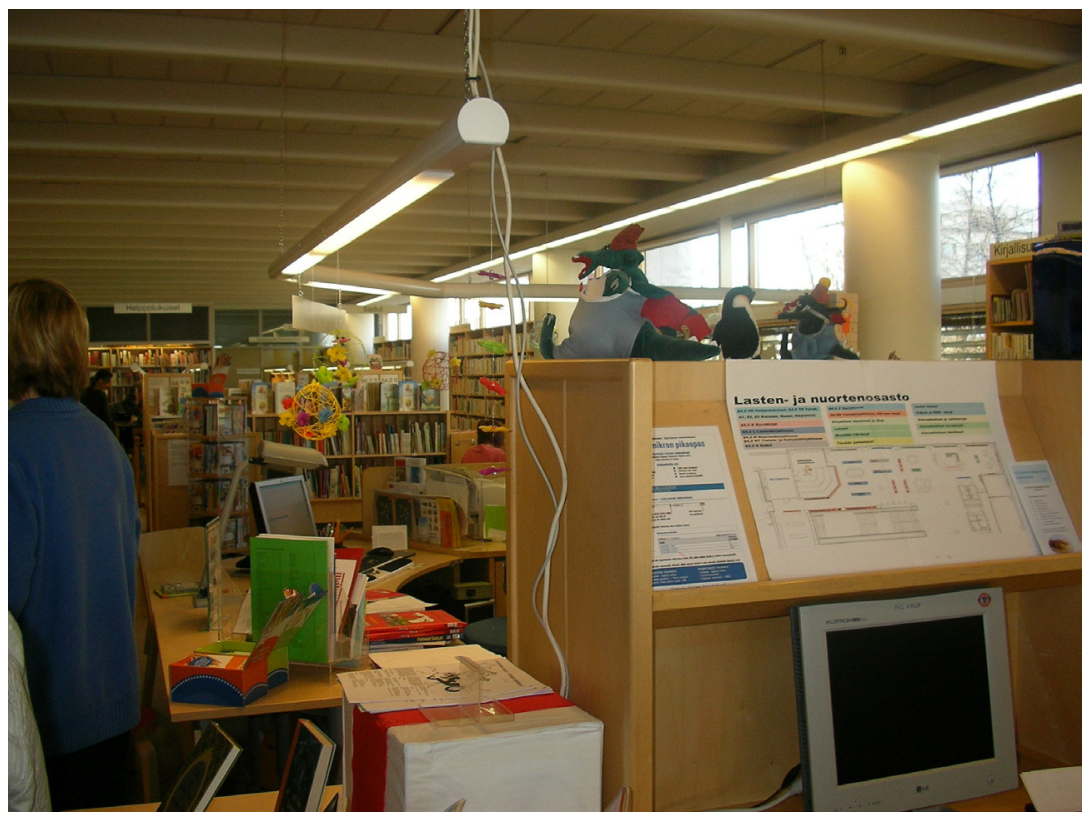

II. I 4. Dział Dziecięcy i Młodzieżowy w Bibliotece Miejskiej w Jyvaskyla Źródło: fot. autorki, 5.05.2008 r.

Oferta, jak wynika z przedstawionego powyżej jej wyboru, jest bogata, zróżnicowana, dostosowana do potrzeb i możliwości tej grupy czytelników, do których jest adresowana (Welcome... 2004, s. 2-4). 
Dział Dziecięcy i Młodzieżowy Miejskiej Biblioteki Publicznej w Jyväskylä koncentruje się na promowaniu czytelnictwa wśród uczniów pozostających na podstawowym i średnim poziomie edukacji.

Stąd też zróżnicowanie przyznawanych za osiągnięcia czytelnicze „Dyplomów Czytania”. „Mały Dyplom Czytania” uzyskać może młody czytelnik po przeczytaniu sześciu książek, zaś dużym dyplomem honoruje się czytelnika po lekturze dwunastu pozycji książkowych.

Efektywne działania CLoP skupiają się wokół współpracy ze szkołami w regionie. Pierwszoplanowym zadaniem jest wprowadzenie uczniów do korzystania z biblioteki. Corocznie, każda szkoła z regionu jest zapraszana do odwiedzania CLoJ, co ma sprzyjać rozwijaniu kompetencji czytelniczych uczniów. Wizyty szkół współgrają z terminarzem imprez organizowanych przez CLoJ.

Wystrój wnętrza, jak i urządzenie części CLoJ przeznaczonej dla potrzeb dzieci i młodzieży, zdaje się odpowiadać potrzebom tych grup czytelników - zarówno pod względem estetycznym i funkcjonalnym, jak i społecznym.

Informatory dotyczące oferty biblioteki oraz zabawne zakładki do książek otrzymują goście CLoJ jako pamiątki z wizyty w tym miejscu wraz z zachętą do powrotu.

Wybrane biblioteki zagraniczne, przedstawione poprzez zaprezentowanie wiodących wątków w ich działalności na rzecz rozwijania kultury czytelniczej dzieci i młodzieży, są bardzo wyraziste. Stanowią one atrakcyjne miejsca w swoich środowiskach i angażują się mocno w przedsięwzięcia kulturalne przekraczające niejednokrotnie lokalne ramy. Ich kształt jest tworzony przez ekspertów i partnersko traktowanych czytelników. Tworzą interesującą przestrzeń łączenia aktywności czytelniczej i kulturalnej, edukacji, rekreacji i rozrywki: jest to najczęściej także przestrzeń wielowymiarowej społecznej inkluzji. 


\section{BIBLIOGRAFIA}

Amrein K., Furrer Y. (2008), Biblioheft 1, Winterthurer Bibliotheken Departement Schule und Sport/Bereich Bildung, Stadt Winterthur, s. 1-23.

Amrein K., Furrer Y. (2008), Biblioheft 5, Winterthurer Bibliotheken Departement Schule und Sport/Bereich Bildung, Stadt Winterthur, s. 1-31.

Bibliotheken machen Schule: Angebote für Primarschulen, Angebote für Primarschulen und Kindergärten (2006), Winterthurer Bibliotheken, Stadt Winterthur, b. p.

Eggert H., Garbe C. (1995), Literarische Sozialisation, Stuttgart, Weimar, Metzler, ISBN 3-476-10287-4

Fiordigigli I., Toscano E. (2008), ADORE Project, 2-nd Example of Good Practice, First level secondary school: „Chiarini - De Lollis” Chieti Foth M. (2006), Sociocultural Animation, [w:] Marshall S., Taylor W., Yu X. (editors), Encyclopedia of Developing Regional Communities with Information and Communication Technology, Hershey, IGI Global, p. 640-645

Guidelines for Library Services to Babies and Toddlers (1997), EAS n. 28 Ortonese Piano locale di Azione per l'Inafanzia, L. 285, CIPI (Centro Interattivo Prima Infanzia), Biblioteca Communale, Ortona

Hall N., Larson J., Smith J. (red.) (2006), Handbook of Early Childhood Literacy, London, Sage, ISBN 978-0-7619-7437-6

Hotz L., Sommer T. (2007), SELEKTISSIMA - Bücher-Voting via Internet. Vorarlberger Schülerinnen und Schüler wählen das Kinder- und Jugendbuch des Jahres 2007, „Rundschreiben Zentrum Lesen“, z. 13, Praxisbeilage 2

Jenkins H. (2006), Convergence Culture: Where Old and New Media Collide, New York, New York University Press, ISBN 978-0-8147-428-5

Kruse G., Sommer T. (2010), Creating an Inspiring Reading Environment [w:] Garbe Ch., Holle K., Weinhold S. (red.), ADORE 
- Teaching Struggling Adolescent Readers in European Countries, Frankfurt am Mein, Peter Lang, s. 133-141

Library Oberwinterthur, Kamishibai in the Spring [online], Winterthurer Bibliotheken, [dostęp: 09.04.2012], dostępny w Internecie: $<$ http://www.winbib.ch/>

Libri in vacanza. Giochi per l'estate (2003), "BiblioRagazzi" (suppl. "Libri in Rete") rok I., nr 3, Comune di Ortona, CESIRA, Centro Sistema Ragazzi, b. p.

Linnakylä P., Välijärvi J., Arffman I. (2007), Reading Literacy - high Qualityby Means of Equity [w:] Linnakylä P., Arffman I. (red.), Reading Literacy in Finland: When Quality and Equity Meet, Jyväskyla, Finnish Institute for Educational Research and University of Jyväskyla, p. 13-33.

Ortona Biblioteca [online], [dostęp: 10.04.2012], dostępny w Internecie: $<$ http:// www.comune.ortona.chieti.it>

Piccole storie Antiche (2007), “BiblioRagazzi” (suppl. „Libri in rete”) rok V, nr 3, Comune di Ortona, Biblioteca Comunale CESIRA, Centro Sistema Ragazzi, b. p.

Sleeter C. E. (1996), Multicultural Education as Social Activism, Albany, State University of New York Press, ISBN 0-7914-2997-0

Schneider H. (2007), "Wenn Schriftaneignung trotzdem gelingt"- Zwischenbericht aus einem Forschungsprojekt der Pädagogischen Hochschule FHNW in Kooperation mit der Universität Basel, der Pädagogischen Hochschule Bern und der Universität Fribourg, „Rundschreiben Zentrum Lesen“, z. 12, s. 2-3.

Welcome to the library! (2004), Jyväskylä, Jyväskylä Public Library-Regional Library of Central Finland, [dostęp: 10.04.2012], dostępny w Internecie: <www.jvaskyla.fi/kirjasto/lentoon> 